\title{
Héros ou victime? L'innovation technique comme transgression sociale au Mexique
}

Aline Hémond

\section{(2) OpenEdition}

12 Journals

Édition électronique

URL : https://journals.openedition.org/tc/350

DOI : $10.4000 /$ tc. 350

ISSN : 1952-420X

Éditeur

Éditions de l'EHESS

\section{Édition imprimée}

Date de publication : 1 juillet 1999

ISSN : 0248-6016

\section{Référence électronique}

Aline Hémond, « Héros ou victime? L'innovation technique comme transgression sociale au

Mexique », Techniques \& Culture [En ligne], 33 | 1999, mis en ligne le 26 octobre 2005, consulté le 29

septembre 2022. URL : http://journals.openedition.org/tc/350 ; DOI : https://doi.org/10.4000/tc.350

Ce document a été généré automatiquement le 29 septembre 2022.

Tous droits réservés 


\section{Héros ou victime? L'innovation technique comme transgression sociale au Mexique}

Aline Hémond 